\title{
Dietary energy level affects adipose depot mass but does not impair in vitro subcutaneous adipose tissue response to short-term insulin and tumor necrosis factor- $\alpha$ challenge in nonlactating, nonpregnant Holstein cows
}

\author{
V. Lopreiato, ${ }^{*}$ A. Hosseini,† F. Rosa,ł Z. Zhou,§ A. Alharthi,† E. Trevisi,ll and J. J. Loor† ${ }^{1}$ \\ *Interdepartmental Services Centre of Veterinary for Human and Animal Health, Department of Health Science, Magna Græcia University, \\ Catanzaro, 88100, Italy \\ †Department of Animal Sciences and Division of Nutritional Sciences, University of Illinois, Urbana 61801 \\ łDairy and Food Science Department, South Dakota State University, 1111 College Ave., 113H Alfred Dairy Science Hall, Brookings 57007 \\ $\S$ Department of Animal and Veterinary Sciences, Clemson University, Clemson, SC 29634 \\ IIDepartment of Animal Sciences, Food and Nutrition, Faculty of Agriculture, Food and Environmental Science, \\ Università Cattolica del Sacro Cuore, Via Emilia Parmense, 84, 29122 Piacenza, Italy
}

\begin{abstract}
We assessed effects of overfeeding energy to nonlactating and nonpregnant Holstein cows during a length of time similar to a typical dry period on body lipid storage and the abundance of genes related to insulin signaling, inflammation, and ubiquitination in subcutaneous adipose tissue (SAT) in vitro challenged with insulin and recombinant bovine tumor necrosis factor- $\alpha$. Fourteen cows were randomly assigned to either a highenergy $(\mathrm{OVE}$; net energy for lactation $=1.60 \mathrm{Mcal} / \mathrm{kg}$ of dry matter; $\mathrm{n}=7$ ) or control (CON; net energy for lactation $=1.30 \mathrm{Mcal} / \mathrm{kg}$ of dry matter; $\mathrm{n}=7$ ) diet for 6 wk. Immediately after slaughter, liver, kidneys, and mammary gland were separated and weighed. The adipose tissue mass in the omental, mesenteric, and perirenal depots was dissected and weighed. Subcutaneous adipose tissue was collected from the tail-head region and was used as follows: control, bovine insulin (INS) at $1 \mu \mathrm{mol} / \mathrm{L}$, tumor necrosis factor- $\alpha$ at $5 \mathrm{ng} /$ $\mathrm{mL}$ (TNF), and their combination. Despite a lack of difference in final body condition score, OVE cows had greater energy intake and were heavier than CON cows. Furthermore, overfeeding led to greater mass of mesenteric and perirenal adipose, liver, and mammary gland. Overall, SAT incubated with INS had an upregulation of insulin receptor (INSR), interleukin 10 (IL10), small ubiquitin-like modifier 3 (SUMO3), and ubiquitin conjugating enzyme E2I (UBC9), whereas TNF upregulated peroxisome proliferator-activated receptor gamma $(P P A R G)$, diacylglycerol O-acyltransferase 2 (DGAT2), interleukin 6 (IL6), nuclear factor kappa B subunit 1 (NFKB1), small ubiquitin-like modifier 2
\end{abstract}

Received January 4, 2018.

Accepted July 4, 2018.

${ }^{1}$ Corresponding author: jloor@illinois.edu
(SUMO2), and UBC9. Regardless of in vitro treatment, feeding OVE upregulated $P P A R G$, fatty acid synthase $(F A S N)$, and insulin induced gene 1 (INSIG1). Abundance of PPARG was greater in SAT of OVE cows cultured individually with INS and TNF. The interaction between diet and in vitro treatment revealed that sterol regulatory element binding transcription factor 1 (SREBF1) had greater abundance in SAT from the CON group in response to culture with INS, whereas SAT from OVE cows had greater SREBF1 abundance in response to culture with TNF. The mRNA abundance of IL6 and NFKB1 was greater in response to TNF treatment and overall in CON cows. Furthermore, SAT from these cows had greater IL10 abundance when cultured with INS and TNF. Overall, data highlighted that overfeeding energy increases adipose tissue mass in part by stimulating transcription of key genes associated with insulin signaling, adipogenesis, and lipogenesis. Because SAT thickness or mass was not measured, the lack of effect of overfeeding on body condition score limits its use to predict overall body lipid storage. An overt inflammatory response in SAT after a 6 -wk period of over-consumption of energy could not be discerned. Key words: nutrition, inflammation, dairy cow, gene abundance

\section{INTRODUCTION}

With its production of adipokines, adipose tissue (AT) plays a crucial role in modulating insulin sensitivity, which can influence glucose metabolism in dairy cows (McCann and Reimers, 1985). Insulin enhances triacylglycerol synthesis in AT through stimulation of lipoprotein lipase and provision of fatty acid substrate, and by simultaneously suppressing lipolysis (Brockman, 1978). Upon insulin stimulation, the phosphorylated insulin receptor substrate (IRS) protein activates 
phosphatidylinositol-3 kinase, which in part signals the translocation of solute carrier family 2 (facilitated glucose transporter), member 4 (SLC2A4) from intracellular sites to the plasma membrane (Saltiel and Kahn, 2001).

In adipocytes, energy is stored primarily as triacylglycerol through uptake of glucose, acetate, and even lactate by activation of lipid-synthesizing enzymes. According to Kim and Spiegelman (1996), at least in nonruminants, these metabolic pathways are under the transcriptional control of sterol regulatory element binding transcription factor 1 (SREBF1). Insulin is an important regulator of the abundance and consequently transcriptional activity of $S R E B F 1$, which in turn regulates the effects of insulin on lipogenesis including regulation of fatty acid synthase (FASN) mRNA abundance (Le Lay et al., 2002).

Another important transcription factor that is critical for the regulation of adipocyte function is the nuclear hormone receptor peroxisome proliferator-activated receptor gamma (PPAR- $\gamma)$. In addition to its stimulatory effect on preadipocyte differentiation, activation of PPAR- $\gamma$ promotes the storage of fatty acids in mature adipocytes (Rosen and Spiegelman, 2001). Furthermore, regulation of adipocyte metabolism by insulin is also exerted through modulation of PPARG expression and activity (Vidal-Puig et al., 1997).

The impairment of insulin signaling [i.e., insulin resistance (IR)] has been defined as either decreased sensitivity or responsiveness to insulin in insulin-sensitive tissues (mainly AT and skeletal muscle; Kahn, 1978). The cytokine tumor necrosis $\alpha$ (TNF- $\alpha$ ), which is overexpressed in AT in obese states, is a key mediator of IR in different rodent models of obesity (Hotamisligil et al., 1993; Hofmann et al., 1994). This cytokine interferes with insulin signaling by repression of IRS1 transcription, decreasing the amount of insulin receptor (INSR), repressing SLC2A4 transcription, and decreasing SLC2A4 mRNA stability (Stephens et al., 1997). Furthermore, TNF- $\alpha$ can induce serine phosphorylation of IRS-1 to inhibit INSR signaling (Hotamisligil et al., 1996).

Adipocyte-derived TNF- $\alpha$ seems to act mainly in an autocrine or paracrine manner (Ofei et al., 1996; Ronti et al., 2006). In this respect, the higher circulating concentrations of TNF- $\alpha$ in obese sheep indicated that AT mass is an important contributor of this cytokine (Daniel et al., 2003). Furthermore, Bradford et al. (2009) detected a doubling of liver triacylglycerol concentration in late-lactation cows injected daily with TNF- $\alpha$. Collectively, these data indicate that circulating amounts of TNF- $\alpha$ arise from adipose depots and disturb physiologic controls of lipid homeostasis.
Previous findings have demonstrated depot-specific differences in the expression of genes encoding important functional and secreted proteins in adipocytes (Lafontan and Berlan, 2003). Evidence of differences between visceral AT (VAT) and subcutaneous AT (SAT) in the proportion of cell types, capillary network, lipid storage capacity, endocrine activity, and responsiveness to lipolytic stimuli have been documented in humans and rodents (Ibrahim, 2010). In dairy cattle, VAT is more sensitive to dietary changes and may have a significant effect on whole-body metabolic responses, particularly in the liver, due to the direct portal drainage (Ji et al., 2012). Previous studies also indicate that VAT is more sensitive to lipolytic stimuli (e.g., catecholamines) but less sensitive to antilipolytic stimulation (insulin) than SAT (Van Harmelen et al., 1997; Giorgino et al., 2005).

We hypothesized that overfeeding leads to greater fat mass deposition accompanied by an impairment of insulin signaling in SAT and a proinflammatory response. Thus, the objective of the present study was to investigate the acute in vitro effects of bovine insulin, recombinant bovine TNF- $\alpha$, or their combination on mRNA abundance of targets related to insulin signaling and responsiveness, adipogenic and lipogenic enzymes/ inducers, inflammatory and anti-inflammatory regulators, and post-translational modifiers in SAT harvested at slaughter from nonlactating, nonpregnant cows fed controlled or higher-energy diets. Those results were also related to measures of BCS and BW, abdominal AT mass, carcass mass, and visceral organs mass.

\section{MATERIALS AND METHODS}

\section{Animal Management, Dietary Treatment, and Feed Analysis}

The Institutional Animal Care and Use Committee of the University of Illinois approved all procedures for this study (protocol \#12134). Fourteen nonlactating, nonpregnant Holstein cows with initial BW of $731 \pm 31$ $\mathrm{kg}$ and initial BCS of $3.31 \pm 0.14$ were enrolled. Cows were housed in ventilated indoor pens $(10 \times 15 \mathrm{~m})$ equipped with individual electronic transmission gates and transponders (American Calan, Northwood, NH) for access to feed; furthermore, cows had light from 0530 to $1430 \mathrm{~h}$. Cows were offered the TMR once daily at $0600 \mathrm{~h}$ and had unlimited access to fresh water. Body weight was recorded twice weekly for all cows before the morning feeding. According to Edmonson et al. (1989), a 5 -point scale BCS $(1=$ thin to $5=$ obese, with quarter-point increments) was assigned to each cow twice daily by 2 individuals and the average score was used for statistical analysis. 
All cows were fed a control diet $\left(\mathbf{C O N} ; \mathrm{NE}_{\mathrm{L}}=1.30\right.$ $\mathrm{Mcal} / \mathrm{kg}$ of DM) to meet $100 \%$ of NRC (2001) requirements at ad libitum intake for 3 wk. After this adaptation period, cows were randomly assigned to receive either a higher-energy diet $\left(\mathbf{O V E} ; \mathrm{NE}_{\mathrm{L}}=1.60 \mathrm{Mcal} /\right.$ $\mathrm{kg}$ of DM; $\mathrm{n}=7)$ or to continue on $\mathrm{CON}(\mathrm{n}=7)$ for 6 wk (Table 1). The CON cows were fed to consume only $100 \%$ of NRC requirements, whereas cows in the OVE group had ad libitum access to feed consuming $\sim 180 \%$ of estimated NRC requirements. The ingredient and nutrient composition of both diets are reported in Table 1. Individual feed ingredients were sampled weekly and DM content was determined for each component. Rations were adjusted for DM content of ingredients on a weekly basis. Representative forage, concentrate mixture, and TMR samples were collected weekly. Analysis of pooled samples was carried out by Dairy One Laboratory (Ithaca, NY) using standard procedures (AOAC International., 1995), and the nutritive values were calculated according to NRC (2001). Net energy intake was calculated by multiplying the daily DMI by $\mathrm{NE}_{\mathrm{L}}$ density of the diet determined from monthly composite samples. Net energy for maintenance was calculated as metabolic BW $\left(\mathrm{BW}^{0.75}\right) \times 0.08$.

\section{Blood Sample Collection and Analyses}

Blood samples were collected before the morning feeding on the day before slaughter from the coccygeal vein or artery. Samples were collected into evacuated tubes (Vacutainer, Becton Dickinson and Co., Franklin Lakes, NJ) containing clot activator or lithium heparin. After blood collection, tubes containing lithium heparin were placed on ice, whereas the tubes with clot activator were kept $\sim 30 \mathrm{~min}$ at $21^{\circ} \mathrm{C}$ until centrifugation. Serum and plasma were obtained by centrifugation of clot activator and lithium heparin tubes, respectively, at $1,900 \times g$ for $15 \mathrm{~min}$ at $4^{\circ} \mathrm{C}$ and frozen at $-80^{\circ} \mathrm{C}$ until later analysis. Biomarkers (Table 2) were analyzed in lithium heparin samples at $37^{\circ} \mathrm{C}$ following the procedures previously described by Osorio et al. (2014) in a clinical auto-analyzer (ILAB 600, Instrumentation Laboratory, Lexington, MA).

\section{Organ and Tissue Weights}

At the end of the 6-wk treatment period, cows were euthanized by captive bolt at the College of Veterinary Medicine diagnostic facilities (University of Illinois). After exsanguination, the BW was determined and is referred to as post-bleed BW. Immediately after death, liver, kidneys, and mammary gland were separated and weighed. The internal AT mass in the omental, great
Table 1. Ingredient and analyzed nutrient composition of the control (CON) and higher-energy (OVE) diets fed to nonpregnant, nonlactating Holstein cows for $6 \mathrm{wk}$

\begin{tabular}{|c|c|c|}
\hline \multirow[b]{2}{*}{ Item } & \multicolumn{2}{|c|}{ Diet } \\
\hline & $\mathrm{CON}$ & OVE \\
\hline \multicolumn{3}{|l|}{ Ingredient, $\%$ of $\mathrm{DM}$} \\
\hline Alfalfa hay & 2.00 & 5.97 \\
\hline Alfalfa silage & 8.88 & 13.61 \\
\hline Ground shelled corn & 4.04 & 12.56 \\
\hline Corn silage & 33.21 & 54.08 \\
\hline Dicalcium phosphate & 0.79 & 0.70 \\
\hline Limestone & 0.82 & 0.84 \\
\hline Magnesium chloride & 0.46 & 0.70 \\
\hline Magnesium oxide & 0.40 & 0.38 \\
\hline Magnesium sulfate & 0.99 & 1.05 \\
\hline Mineral-vitamin premix ${ }^{1}$ & 0.20 & 0.21 \\
\hline Salt & 0.20 & 0.14 \\
\hline Soybean meal, $48 \%$ CP & 11.56 & 4.35 \\
\hline Urea & 0.20 & 0.19 \\
\hline Vitamin $A^{2}$ & 0.01 & 0.01 \\
\hline${\text { Vitamin } D^{3}}^{3}$ & 0.01 & 0.01 \\
\hline Vitamin $E^{4}$ & 0.26 & 0.24 \\
\hline Wheat straw & 35.97 & - \\
\hline Whole cottonseeds & - & 4.98 \\
\hline Total forage, $\%$ of DM & 80.06 & 78.64 \\
\hline Total concentrate, $\%$ of DM & 19.94 & 21.38 \\
\hline \multicolumn{3}{|l|}{ Chemical analysis } \\
\hline $\mathrm{NE}_{\mathrm{L}}{ }^{5} \mathrm{Mcal} / \mathrm{kg}$ & 1.30 & 1.60 \\
\hline $\mathrm{CP}, \% \mathrm{DM}$ & 14.08 & 14.45 \\
\hline $\mathrm{ADF}, \% \mathrm{DM}$ & 34.40 & 26.30 \\
\hline $\mathrm{NDF}, \% \mathrm{DM}$ & 50.40 & 38.30 \\
\hline
\end{tabular}

${ }^{1}$ Contained a minimum of $5 \% \mathrm{Mg}, 10 \% \mathrm{~S}, 7.5 \% \mathrm{~K}, 2.0 \% \mathrm{Fe}, 3.0 \% \mathrm{Zn}$, $3.0 \% \mathrm{Mn}, 5,000 \mathrm{mg} / \mathrm{kg}$ of $\mathrm{Cu}, 250 \mathrm{mg} / \mathrm{kg}$ of I, $40 \mathrm{mg} / \mathrm{kg}$ of Co, 150 $\mathrm{mg} / \mathrm{kg}$ of Se, 2,200 IU/ $\mathrm{kg}$ of vitamin $\mathrm{A}, 660 \mathrm{IU} / \mathrm{kg}$ of vitamin $\mathrm{D}_{3}$, and $7,700 \mathrm{IU} / \mathrm{kg}$ of vitamin $\mathrm{E}$.

${ }^{2}$ Contained 30,000 kIU/kg.

${ }^{3}$ Contained 5,009 kIU $/ \mathrm{kg}$.

${ }^{4}$ Contained 44,000 IU $/ \mathrm{kg}$.

${ }^{5}$ Calculated using the Dairy Cattle NRC (2001) model. Inputs were 8.5 $\mathrm{kg}$ of DMI for CON or $14.4 \mathrm{~kg}$ of DMI for OVE. A BW of $717 \mathrm{~kg}$ was the input for both diets.

mesenteric, and perirenal depots was dissected and weighed. The final weight of the animal after removal of blood, all internal organs, and mammary gland constituted the empty carcass weight.

Table 2. Biomarkers of metabolism, liver function, and inflammation, in plasma from nonpregnant, nonlactating dairy cows fed a control (CON, $1.30 \mathrm{Mcal} / \mathrm{kg} ; \mathrm{n}=7$ ) or high-energy (OVE, $1.60 \mathrm{Mcal} / \mathrm{kg} ; \mathrm{n}$ $=7$ ) diet for $6 \mathrm{wk}$

\begin{tabular}{|c|c|c|c|c|}
\hline \multirow[b]{2}{*}{ Item } & \multicolumn{2}{|c|}{ Diet } & \multirow[b]{2}{*}{ SEM } & \multirow[b]{2}{*}{$P$-value } \\
\hline & $\mathrm{CON}$ & OVE & & \\
\hline Glucose, $\mathrm{mmol} / \mathrm{L}$ & 4.52 & 4.69 & 0.09 & 0.20 \\
\hline Cholesterol, mmol/L & 2.64 & 3.90 & 0.24 & 0.004 \\
\hline Fatty acids, mmol/L & 0.17 & 0.07 & 0.02 & 0.002 \\
\hline $\mathrm{BHB}, \mathrm{mmol} / \mathrm{L}$ & 0.22 & 0.43 & 0.03 & 0.0002 \\
\hline Haptoglobin, g/L & 0.27 & 0.14 & 0.07 & 0.08 \\
\hline Bilirubin, $\mu \mathrm{mol} / \mathrm{L}$ & 1.49 & 0.89 & 0.13 & 0.005 \\
\hline
\end{tabular}




\section{SAT Collection and In Vitro Challenge}

Subcutaneous AT samples were collected from tailhead region immediately postslaughter and brought to the laboratory in endotoxin-free Dulbecco's Modified Eagle's Medium and Ham's F-12 nutrient mixture (DMEM:F-12; Sigma-Aldrich, St. Louis, MO) within 30 min. Before incubation and treatment, $4 \mathrm{~g}$ of dissected tissue was carefully processed to remove adjacent non$\mathrm{AT}$ and blood, and dissected in subsamples of $500 \mathrm{mg}$. Subsamples were then minced into smaller fragments and used for 1 of 4 treatments: control, bovine insulin (INS) at $1 \mu \mathrm{mol} / \mathrm{L}$ (\#128L-10, Fisher Scientific, Hampton, NH), recombinant bovine TNF- $\alpha$ (TNF) at $5 \mathrm{ng} / \mathrm{mL}$ (RBOTNFAI, Pierce Endogen, Rockford, IL), and their combination (TNF-INS). These doses were chosen to resemble plasma levels achieved in the cow studies of Ji et al. (2012) and Bradford et al. (2009). The medium used was DMEM:F-12 with additional penicillin streptomycin $(100 \mu \mathrm{g} / \mathrm{mL}$; Pen/Streptomycin; Sigma-Aldrich) and all treatments were performed in duplicate. Tissue subsamples were cultured in $4 \mathrm{~mL}$ of medium in 6-well plates and incubated in a waterjacketed $\mathrm{CO}_{2}$ incubator. Incubations were carried out at $37^{\circ} \mathrm{C}$ for $2 \mathrm{~h}$ with $5 \% \mathrm{CO}_{2}$. This length of incubation was chosen based on previous in vitro work from our group and others (McNamara et al., 1995; Mukesh et al., 2010). At the end of the incubation period, SAT was transferred to a tube containing Quiazol reagent (Qiagen Inc., Valencia, CA), homogenized with a tissue homogenizer, and stored at $-80^{\circ} \mathrm{C}$ until RNA extraction.

\section{Target Genes, RNA Extraction, cDNA Synthesis, and Quantitative PCR}

We selected genes for transcript profiling based on associations with traits. Insulin receptor substrate 1 (IRS1), INSR, and SLC2A4 were associated with insulin signaling and responsiveness. Fatty acid synthase (FASN), PPARG, SREBF1, diacylglycerol O-acyltransferase 2 (DGAT2), and insulin-induced gene 1 (INSIG1) were associated with adipogenic and lipogenic enzymes/inducers. Nuclear factor kappa B subunit 1 (NFKB1), interleukin-6 (IL6), interleukin-10 (IL10), and serum amyloid A 3 (SAA3) were associated with inflammatory and anti-inflammatory regulators. Small ubiquitin-like modifier 2 (SUMO2), small ubiquitinlike modifier 3 (SUMO3), and ubiquitin conjugating enzyme E2I $(U B C 9)$ were associated with and posttranslational modifiers.

Complete details of the procedures are presented in the Supplemental Material and Supplemental Tables S1 and S2 (https://doi.org/10.3168/jds.2018-14389).
Briefly, total RNA extraction was performed following the procedure recommended by Qiagen (miRNeasy Mini Kit; Cat. \# 217004, Hilden, Germany). The RNA concentration was measured with a Nano-Drop ND-1000 spectrophotometer (Nano-Drop Technologies, Wilmington, DE), whereas the quality was evaluated using the Agilent 2100 Bioanalyzer (Agilent Technologies, Santa Clara, CA). The cDNA was synthesized from $100 \mathrm{ng}$ of RNA using Eppendorf Mastercycler Gradient (Eppendorf, Hamburg, Germany) and following established protocols in our laboratory (Bionaz et al., 2012; Khan et al., 2014). The quantitative PCR was based on SYBR Green (Quanta Bioscience Inc., Gaithersburg, MD) using a 6-point standard curve plus the nontemplate control. The amplicons were sequenced and the fragment sequences were blasted and confirmed using the National Center of Biotechnology Information (NCBI, https://blast.ncbi.nlm.nih.gov/ Blast.cgi). The geometric mean of the internal control genes glyceraldehyde-3-phosphate dehydrogenase $(G A P D H)$, ribosomal protein S9 (RPS9), and ubiquitously expressed transcript ( $U X T)$ were used for data normalization.

\section{Statistical Analysis}

Body weight, BCS, and tissue and organ masses were examined for normality of distribution and homogeneity of residuals variance using Proc Univariate of SAS 9.3 (SAS Institute Inc., Cary, NC). Data were analyzed using Proc Mixed of SAS. Nonrepeated data (BW, BCS, blood biomarkers, and tissue and organ masses) were analyzed as a randomized design with a mixed model containing the fixed effect of diet; models also contained the covariates of initial BCS and pretrial BW as continuous variables if $P<0.05$. After normalization with the geometric mean of the internal control genes, the triplicate quantitative PCR data for each gene were averaged and then $\log _{2}$ transformed before statistical analysis to obtain a normal distribution. All mRNA abundance data were analyzed with Proc MIXED procedure of SAS 9.3 (SAS Institute Inc.). Fixed effects in the model were diet $(\mathbf{D})$, without $(\mathbf{N})$ or with $(\mathbf{Y})$ INS, without (N) or with $(\mathbf{Y})$ TNF, and the interaction INS $\times$ TNF, $\mathrm{D} \times \mathrm{INS}, \mathrm{D} \times \mathrm{TNF}$, and $\mathrm{D} \times \mathrm{INS}$ $\times$ TNF. Cow within diet was the random effect. The Kenward-Roger statement was used for computing the denominator degrees of freedom, whereas the covariance structure used in the analysis was the variance components. Statistical significance was declared at $P$ $<0.05$ using the PDIFF statement in SAS. The mRNA abundance data reported in all figures are the $\log _{2}$ back-transformed least squares means resulting from the statistical analysis. 


\section{RESULTS}

\section{Final BW and BCS, Postslaughter Organ Weights, and AT Mass}

Throughout the experiment, OVE cows had greater $\mathrm{NE}_{\mathrm{L}}$ intake than $\mathrm{CON}$ cows (19.91 and $10.58 \mathrm{Mcal} / \mathrm{d}$, respectively; $P<0.05)$. Least squares means \pm standard error of the means of final $\mathrm{BW}$ and postslaughter weights (A), mass of adipose depots (B), and organ weights (C) are depicted in Figure 1. Cows in OVE had greater final $\mathrm{BW}$ than $\mathrm{CON}$ cows $(P<0.001)$, but we found no difference for final BCS, which averaged 3.21 and 3.43 for CON and OVE cows, respectively. Postbleed and empty carcass weight did not differ between groups. Mesenteric and perirenal AT mass was greater for cows fed OVE compared with CON $(P<0.05)$; however, omental AT mass was not affected. Weights of liver and mammary gland were greater for OVE than CON cows $(P<0.0001$ and $P<0.05$, respectively).

\section{Blood Biomarkers}

Blood concentrations of biomarkers are reported in Table 2. The OVE cows had greater $(P<0.05)$ concentrations of cholesterol (3.90 vs. $2.64 \mathrm{mmol} / \mathrm{L}$, respectively, for $\mathrm{OVE}$ and $\mathrm{CON}$ ) and $\mathrm{BHB}$ (0.43 vs. $0.22 \mathrm{mmol} / \mathrm{L}$, respectively, for OVE and CON) as well as lower $(P<0.05)$ fatty acids $(0.07$ vs. $0.17 \mathrm{mmol} / \mathrm{L}$, respectively, for OVE and CON). Bilirubin was lower $(P<0.05)$ in cows fed OVE $(0.89$ vs. $1.49 \mu \mathrm{g} / \mathrm{mol}$, respectively, for OVE and CON). Furthermore, haptoglobin tended to be lower in OVE cows $(P \leq 0.08 ; 0.14$ vs. $0.27 \mathrm{~g} / \mathrm{L}$, respectively, for OVE and $\mathrm{CON}$ ).

\section{Gene Expression of In Vitro Challenged SAT}

Main effect of in vitro treatments (INS or TNF) and their interaction (INS $\times \mathrm{TNF}$ ) are reported in Table 3 , whereas the main effect of diet (D) and its interaction with in vitro treatment $(\mathrm{D} \times \mathrm{INS}, \mathrm{D} \times \mathrm{TNF}$, or $\mathrm{D}$ $\times$ INS $\times$ TNF) are reported in Table 4. Overall, INS upregulated INSR, IL10, SUMO3, and UBC9 mRNA abundance in SAT $(P<0.05)$, whereas TNF upregulated PPARG, DGAT2, IL6, NFKB1, SUMO2, and $U B C 9$ mRNA abundance $(P<0.05)$.

\section{Insulin Signaling and Responsiveness}

The interaction of INS $\times$ TNF affected mRNA abundance of INSR and IRS1 $(P<0.001)$. The SAT treated with the combination INS-TNF had greater mRNA abundance of INSR (Table 3). Similarly, IRS1 abundance was greater with the INS-TNF treatment
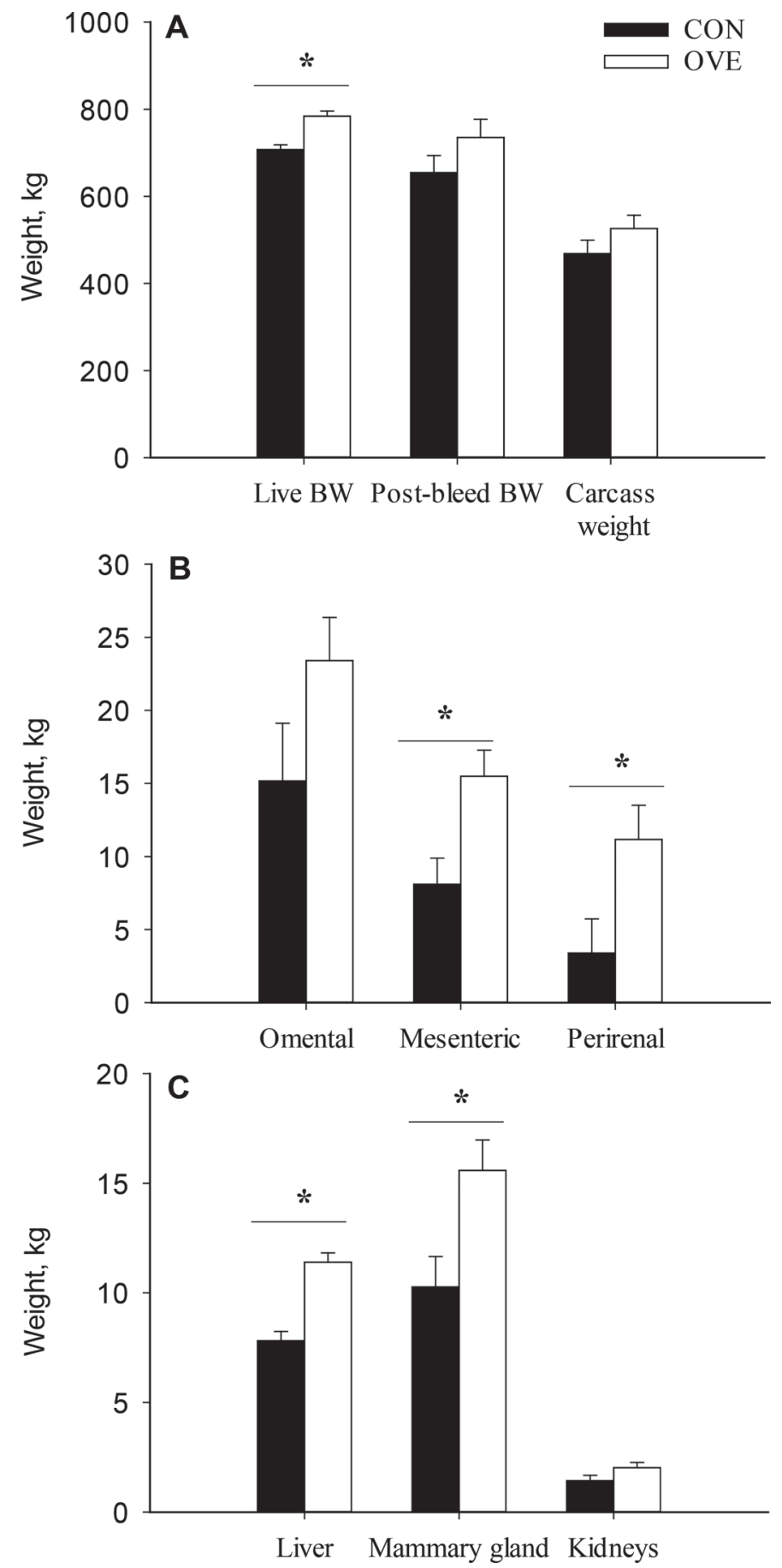

Figure 1. Final live BW, post-bleed BW, and post-slaughter carcass weight (A), adipose depot mass (B), and organ weight (C) in nonlactating, nonpregnant dairy cows fed either a control diet (CON; $1.30 \mathrm{Mcal} / \mathrm{kg} ; \mathrm{n}=7$ ) or high-energy $\operatorname{diet}(\mathrm{OVE} ; 1.60 \mathrm{Mcal} / \mathrm{kg} ; \mathrm{n}=7$ ). Asterisk $(*)$ indicates differences between CON and OVE diet, $P<$ 0.05. Error bars indicate SEM.

compared with the individual INS and TNF treatments; furthermore, a $\mathrm{D} \times \mathrm{INS}$, and $\mathrm{D} \times \mathrm{TNF}$ effect was detected $(P \leq 0.01$; Table 4$)$. Overall, SAT 
DIETARY ENERGY AND ADIPOSE INSULIN SENSITIVITY

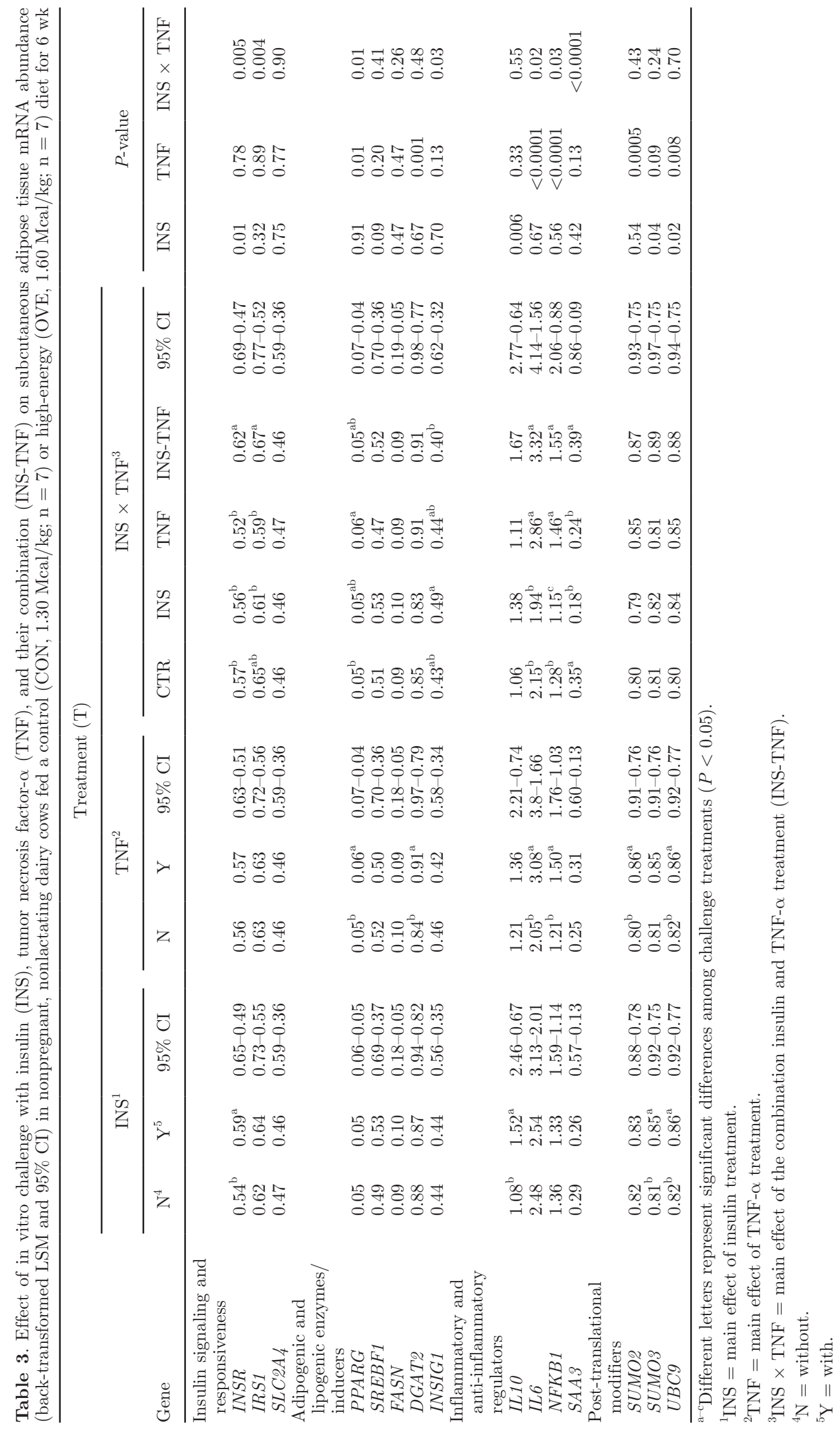




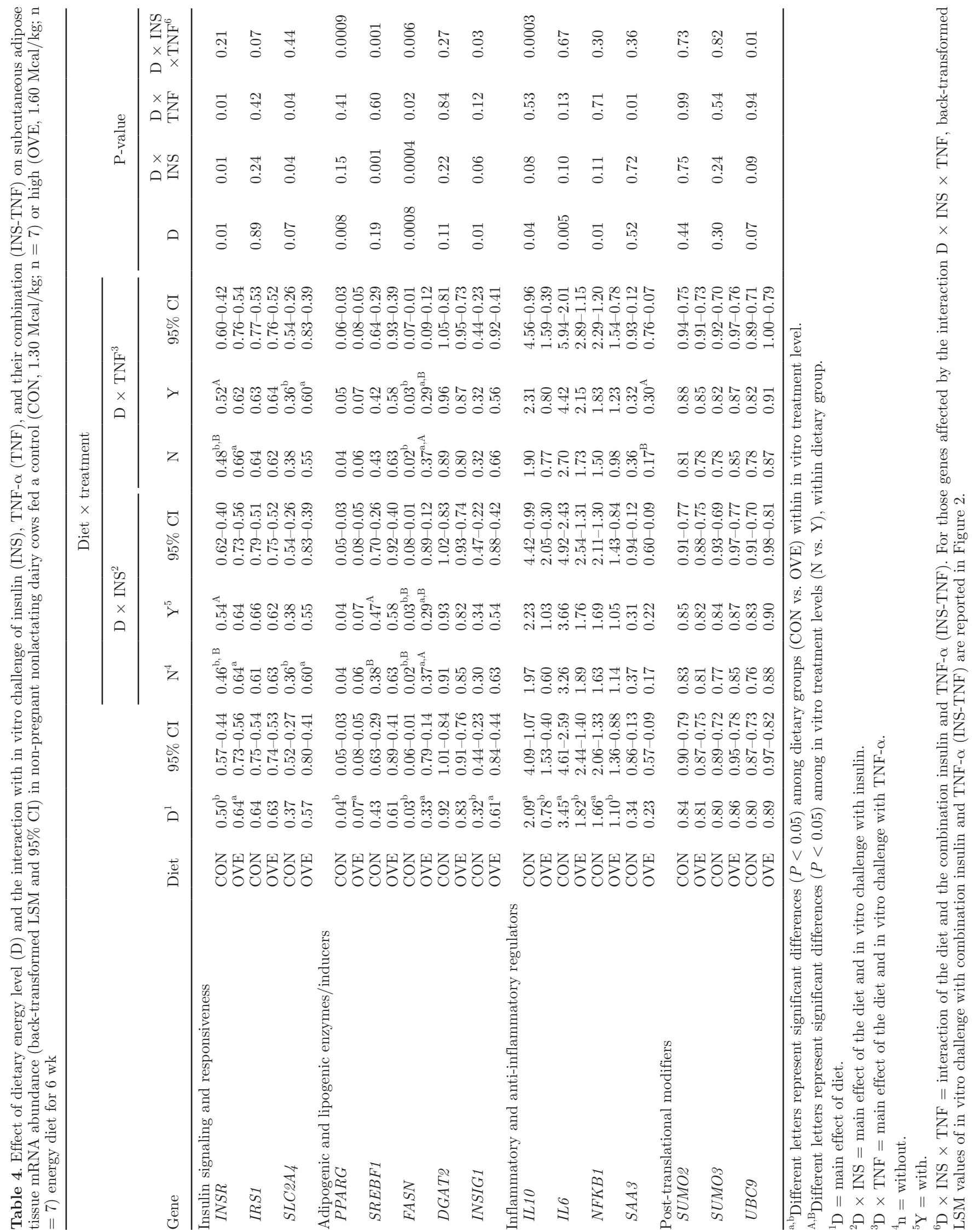


of OVE compared with CON cows had greater mRNA abundance of INSR; however, factorial analysis determined the lower abundance of INSR in CON cows was increased by either the INS or the TNF, whereas the higher abundance of INSR in OVE cows was increased no further by either INS or TNF $(P \leq 0.05$; Table $4)$. The SAT of OVE compared with CON cows had greater $S L C 2 A 4$ abundance in response to culture with TNF $(P<0.05$; Table 4$)$.

\section{Adipogenic and Lipogenic Enzymes/Inducers}

The TNF treatment $(P \leq 0.01)$ led to greater (Y vs. N) abundance of PPARG and DGAT2 (Table 3). Regarding PPARG, an interaction within treatment was observed as the TNF group had greater abundance compared with all other groups $(\mathrm{INS} \times \mathrm{TNF}$; $P<0.05)$. Regardless of in vitro treatment, feeding OVE upregulated PPARG, FASN, and INSIG1 $(P \leq$ 0.01 ; Table 4$)$. A $\mathrm{D} \times \mathrm{TNF}$ effect $(P<0.05)$ was observed for $F A S N$ due to an overall greater abundance in OVE independent of TNF addition. For all 3 genes, an interaction among all treatments was observed (D $\times$ INS $\times$ TNF; $P<0.05$; Figure 2). Overall, SAT of OVE cows had greater FASN abundance independent of in vitro treatments (Table 4). The SAT of OVE cows had greater PPARG abundance (Figure 2A) when cultured individually with INS (0.07 vs. 0.04 for OVE and CON, respectively; $P<0.05$ ) or TNF (0.08 vs. 0.05 for OVE and CON, respectively; $P<0.05)$. The D $\times$ INS interactions $(P<0.05)$ revealed that $S R E B F 1$ had greater abundance in SAT from the CON group in response to culture with insulin ( $\mathrm{Y}>\mathrm{N}$; Table 4), whereas the interaction $\mathrm{D} \times \mathrm{INS} \times \mathrm{TNF}$ pointed out a lower SREBF1 abundance in SAT from CON cows in response to culture with TNF $(0.63$ vs. 0.35 for OVE and $\mathrm{CON}$, respectively; $\mathrm{D} \times \mathrm{INS} \times \mathrm{TNF}, P<0.05$; Figure 2B).

\section{Inflammatory and Anti-Inflammatory Regulators}

An effect of TNF and INS $\times$ TNF was detected for IL6 and NFKB1 $(P<0.05)$ due to the greater abundance in SAT cultured individually with TNF and in combination with INS (Table 3). Abundance of NFKB1 was lower in SAT treated with INS compared with NFKB1 abundance in CTR-, TNF- or INS-TNF-treated SAT $(P<0.05$; Table 3$)$. The combination of INSTNF led to a greater $S A A 3$ abundance compared with culture with INS or TNF individually (INS $\times$ TNF; $P$ $<0.0001$; Table 3). Regardless of in vitro treatments, SAT of CON cows had greater abundance of IL10, IL6, and NFKB1 but no $\mathrm{D} \times \mathrm{INS}$ or $\mathrm{D} \times \mathrm{TNF}$ effects were observed $(P>0.05$; Table 4$)$. The TNF treatment led to a greater $S A A 3$ abundance in OVE compared with CON cows $(\mathrm{D} \times \mathrm{TNF} ; P \leq 0.01$; Table 4$)$. A 3 -way interaction $(\mathrm{D} \times \mathrm{INS} \times \mathrm{TNF} ; P<0.001$; Table 4$)$ was detected for IL10. Indeed, differences in mRNA abundance of $I L 10$ after individual treatment with INS (0.78 vs. 2.04 for OVE and CON, respectively; Figure $2 \mathrm{E}$ ) or TNF (0.47 vs. 2.62 for OVE and CON, respectively; Figure 2E) revealed that overall CON cows had greater abundance of IL10 compared with OVE $(P<$ 0.05 ; Table 4).

\section{Post-Translational Modifiers}

Overall SUMO2 and UBC9 abundance (Table 3) was greater in SAT cultured with TNF $(\mathrm{Y}>\mathrm{N} ; P$ $<0.01)$. Furthermore, culture with INS resulted in greater abundance of $S U M O 3$ and $U B C 9(\mathrm{Y}>\mathrm{N} ; P$ $<0.05)$. We found a $\mathrm{D} \times \mathrm{INS} \times \mathrm{TNF}$ interaction for UBC9 abundance $(P \leq 0.01$; Table 4$)$, resulting in a greater $U B C 9$ abundance in OVE compared with CON cows when incubations contained TNF (0.93 vs. 0.77 for OVE and CON, respectively; Figure 2F).

\section{DISCUSSION}

\section{Final BW and BCS, Postslaughter Organ Weights, AT Mass, and Blood Metabolites}

The greater final BW between OVE and CON without differences in final BCS are consistent with a previous report from a similar experiment (Drackley et al., 2014), and could be partly explained by the fact that dairy compared with beef breeds of cattle accumulate relatively more fat in internal adipose depots and less in subcutaneous fat (Wright and Russel, 1984). Although Drackley et al. (2014) reported differences in omental adipose weight between cows fed high- and low-energy, the lack of difference in the present study could be ascribed in part to differences in length of experimental period (6 vs. $8 \mathrm{wk}$ ). It also could be possible that the number of cows enrolled in the present study was not enough to reduce variation, hence the lack of statistical difference in omental adipose mass. However, differences in mesenteric and perirenal adipose depot mass between groups support the hypothesis that internal adipose depots are responsible for overall increases in energy storage in energy-overfed cows.

Reynolds et al. (2004) observed that feeding supplemental barley to cows in late-gestation increased mesenteric fat mass, but mesenteric fat mass did not change when a similar amount of ME was supplied as rumenprotected protein. Clearly, those data indicate specific effects of fermentable carbohydrates on VFA production and absorption and its effects on glucose availability. 

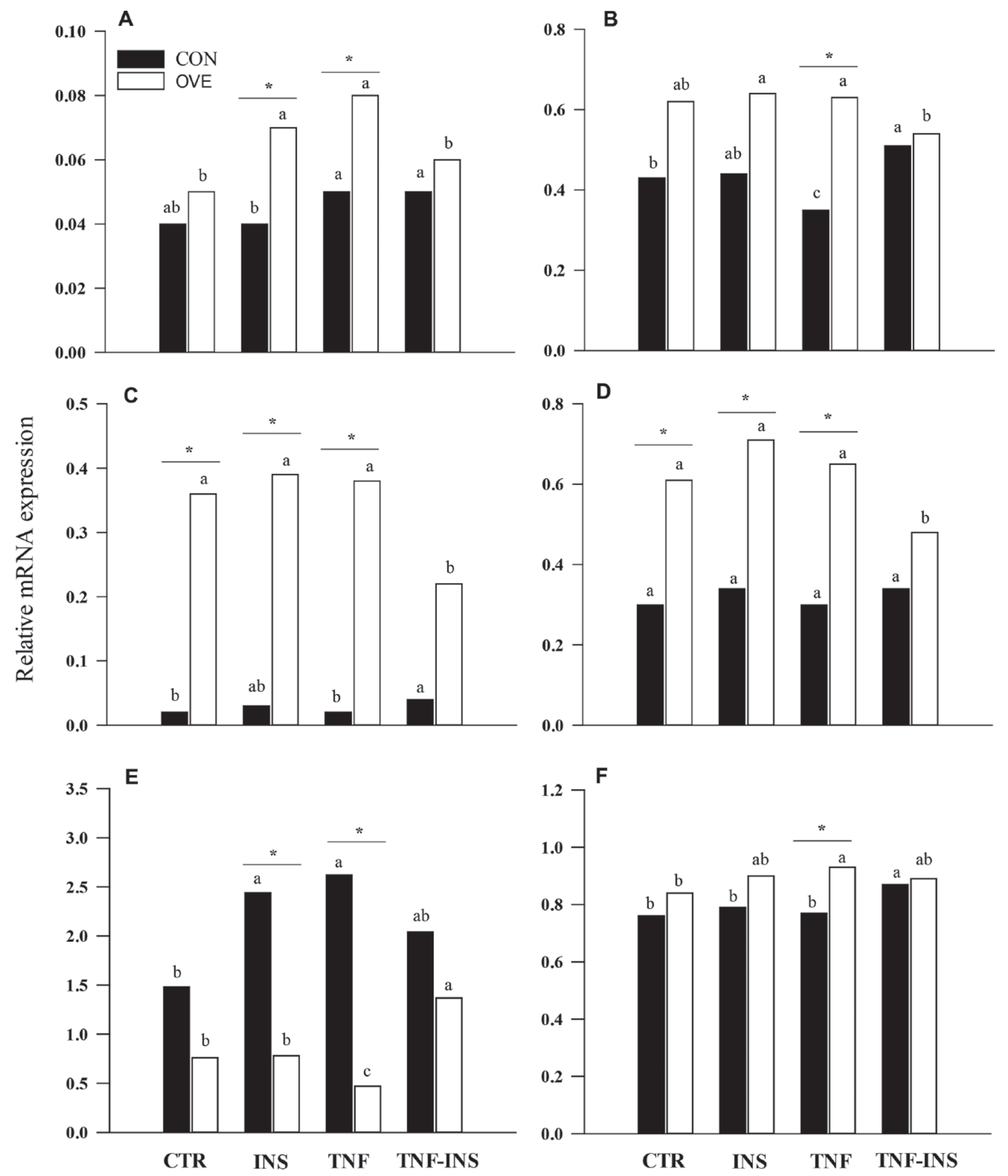

In vitro treatment

In vitro treatment

Figure 2. Effects of a 2-h in vitro challenge of subcutaneous adipose tissue with insulin (INS; $1 \mu$ mol/L), tumor necrosis factor- $\alpha$ (TNF; $5 \mathrm{ng} / \mathrm{mL}$ ), and their combination (TNF-INS) on abundance of lipogenic enzymes/inducers (A, PPARG; B, SREBF1; C, FASN; D, INSIG1), anti-inflammatory cytokine (E, IL10), and post-translational regulator $(\mathrm{F}, U B C 9)$. Adipose tissue was harvested from nonlactating, nonpregnant dairy cows fed either a control diet $(\mathrm{CON}, 1.30 \mathrm{Mcal} / \mathrm{kg} ; \mathrm{n}=7)$ or high-energy diet (OVE, $\left.1.60 \mathrm{Mcal} / \mathrm{kg}^{\prime} \mathrm{n}=7\right)$. Values are log back- $^{2}$ transformed LSM. Asterisk $\left(^{*}\right)$ indicates differences between CON and OVE diet, $P<0.05$. Significant differences between in vitro treatments are represented by different letters $(\mathrm{a}-\mathrm{c} ; \mathrm{P}<0.05)$. CTR $=$ control. 
In the present study, the higher fermentable carbohydrate intake in OVE cows enhanced postruminal supply of energy, resulting in the stimulation of lipogenesis mainly within abdominal fat depots and agrees with a previous report (Baldwin et al., 2007). Regardless of physiological state, increasing the level of nutrient supply to ruminants generally leads to greater visceral organ mass (Burrin et al., 1990), which we detected for liver and mammary gland. As suggested by Drackley et al. (2014) in a similar study, the difference in liver mass detected in the present study suggests greater nutrient supply via the portal flow in OVE compared with CON cows. Increasing energy intake results in greater nutrient and energy absorption across portal-drained viscera including VFA, L-lactate, glucose, and AA (Reynolds and Huntington, 1988; Reynolds et al., 2003).

Compared with CON cows, the greater plasma BHB coupled with lower fatty acids concentrations in OVE cows suggested they were in more positive energy balance. According to Reynolds et al. (1988), greater intakes of DM and ME lead to more rumen-fermentable $\mathrm{OM}$ that results in greater ruminal butyrate and, consequently, higher circulating BHB. The fact that plasma concentration of cholesterol was greater in OVE cows, coupled with a lower concentration of haptoglobin and bilirubin, reflects better liver functionality and the absence of systemic inflammation. Indeed, the liver represents the major site of cholesterol synthesis and metabolism in ruminants (Nestel et al., 1978). In addition, greater mammary gland weight in OVE cows could have been due to greater circulating acetate and BHB, which represent the main precursors for fatty acid synthesis (Bauman et al., 1970). As we used nonlactating, nonpregnant cows, it is likely that feeding OVE enhanced fatty acid synthesis in mammary gland tissue, particularly the fat pad.

\section{Gene Abundance}

Studies using euglycemic clamps (Petterson et al., 1993) and glucose tolerance tests (Schoenberg and Overton, 2011) demonstrated that late pregnancy in sheep and cows is characterized by altered IR. However, mRNA and protein abundance data from cows overfed a higher-energy diet during the last $\sim 20$ to $30 \mathrm{~d}$ prepartum revealed normal or enhanced insulin signal transduction in SAT prepartum along with greater plasma fatty acids postpartum compared with cows that received a controlled-energy diet (Ji et al., 2012). This type of discrepancy could be related to the fact that skeletal muscle is the most important user of glucose; that is, the glucose tolerance test data reflect peripheral utilization of glucose primarily by muscle (DeFronzo and Tripathy, 2009). Gene expression data herein highlighted that overfed cows had an overall upregulation of insulin signaling genes associated (especially at the receptor level) with adipogenic regulators and lipogenic enzymes.

Insulin promotes storage of triacylglycerol in adipocytes by several mechanisms, including fostering the differentiation of preadipocytes to adipocytes and, in mature adipocytes, stimulating glucose transport, lipogenesis, and esterification (triacylglycerol synthesis), as well as inhibiting lipolysis (Kahn and Flier, 2000). Insulin resistance can result in the decrease of insulin binding to its receptor, receptor phosphorylation and tyrosine kinase activity, and phosphorylation of IRS (Kahn and Flier, 2000). Similar to our previous in vivo study (Ji et al., 2012), data on INSR, IRS1, and $S L C 2 A 4$ mRNA suggested that overfeeding enhanced insulin sensitivity and responsiveness. The clearest evidence for the greater insulin sensitivity in OVE cows was the greater PPARG, SREBF1, FASN, and INSIG1 mRNA abundance.

Because both INSR and IRS-1 are central to normal insulin action, the fact that insulin challenge in vitro, regardless of dietary energy level, only upregulated INSR offers further support to the idea that overfeeding did not affect the ability of insulin to stimulate glucose transport. Staubs et al. (1998) discussed how glucose transport could occur independently of IRS-1 stimulation. The simplest interpretation is that insulin stimulation of IRS-1 tyrosine phosphorylation, with its subsequent binding to and activation of phosphatidylinositol 3-kinase, is not important for stimulation of glucose transport. Alternatively, it is possible that insulin stimulates glucose transport by at least 2 parallel pathways; if one of these pathways involves IRS-1, then the alternate pathway through Casitas b-lineage lymphoma/Cbl associated protein/Rho-family GTPase TC10 (Yang et al., 2013) counterbalances the blockade of IRS-1.

The increased dietary energy level in OVE cows was primarily derived from greater amounts of starch; thus, OVE cows likely had greater rates of glucose entry from either postruminal absorption or increased gluconeogenesis from propionate. Based on nonruminant research, a mechanism to explain the greater abundance of PPARG, SREBF1, and INSIG1 mRNA in OVE compared with CON cows is that increased postabsorptive glucose availability can directly stimulate lipogenic gene expression through an increase in insulin concentration and a subsequent stimulation of adipogenesis through the activation of a cascade of transcription factors including PPARG, SREBF1, and INSIG1 (Rosen and Spiegelman, 2006). These transcription factors orchestrate the expression of lipogenic genes and maturation of adipocytes that actively store lipid. 
Peroxisome proliferator-activated receptor gamma, the primary transcription regulator in PPAR signaling, is a key factor controlling the transcription of many genes that are involved in adipogenesis (Loor et al., 2013). Thus, in a previous study we pointed out that the overall upregulation of $P P A R G$ in AT depots in response to dietary energy likely contributes to the transcriptional control of adipogenesis or lipogenesis in bovine AT (Ji et al., 2014). This idea is supported by the upregulation of $F A S N$ in the present study, indicating that de novo fatty acid synthesis was responsive to dietary changes at least in part through transcriptional adaptations.

Previous studies in 3T3-L1 adipocytes indicated that insulin resistance after prolonged exposure to $\mathrm{TNF}-\alpha$ $(72-96 \mathrm{~h})$ occurs partly due to downregulation of $S C L 2 A 4$ or diminished insulin receptor signaling at the level of IRS-1 tyrosine phosphorylation (Stephens and Pekala, 1991, 1992; Hotamisligil et al., 1994, 1996). At least in the short term, our data seem to suggest no impairment of insulin signaling or adipogenic or lipogenic gene expression in response to TNF- $\alpha$, which agrees with some of the data from Stephens et al. (1997). In addition, dosing only TNF- $\alpha(250 \mathrm{p} M)$ or TNF- $\alpha$ in combination with $50 \mathrm{n} M$ of insulin had essentially no effect on basal or insulin-stimulated glucose uptake within 24 h of treatment (Stephens et al., 1997). Furthermore, insulin-stimulated glucose uptake was unaffected by $1 \mathrm{n} M$ TNF- $\alpha$ for 1 and $6 \mathrm{~h}$ and, in fact, a slight decrease in uptake was noted at $24 \mathrm{~h}$ (Stephens et al., 1997).

To ascertain whether TNF- $\alpha$ can directly stimulate release of fatty acids from adipocytes, work in rodents has used exogenous TNF- $\alpha$ treatment of immortalized 3T3-L1 adipocytes (Ruan et al., 2002). Data indicate a marked increase in fatty acid release after only $8 \mathrm{~h}$ of culture, with elevated concentrations of fatty acids remaining 2.3-fold higher than baseline $24 \mathrm{~h}$ after TNF- $\alpha$ challenge. The response in fatty acids release was associated with lower abundance of various proteins involved in the utilization and storage of fatty acids (Ruan et al., 2002); for example, genes encoding adipocyte fatty acid-binding protein, acyl-CoA-binding protein, long-chain fatty acyl CoA synthase, diacylglycerol acyltransferase, and perilipin A. Although exogenous TNF- $\alpha$ clearly can elicit a potent lipolytic response in rodents in a short time frame, it is possible that the 2-h incubation used in the present study was not enough for TNF- $\alpha$ to compromise insulin signaling and expression of genes encoding adipogenic and lipogenic enzymes. However, regardless of diet, the fact that the challenge with TNF- $\alpha$ upregulated $I L 6$ and NFKB1 suggests that $2 \mathrm{~h}$ of incubation led to a rapid inflammatory response.
An additional consideration in the context of biological interpretation is that animals used for the scope of this work were overfed and cannot be considered as an obesity model. Relative to rodent models of obesity, the apparent discordant results obtained after TNF- $\alpha$ stimulation could be explained in part by dose of TNF- $\alpha$ and time of exposure $(2 \mathrm{~h})$ not being sufficient to induce lower mRNA abundance of PPARG, FASN, and INSIG1. This idea is supported by rodent data in which exposure of adipocytes for longer than $2 \mathrm{~h}$ was needed to induce lipolysis and downregulation of PPARG, FASN, and INSIG1 (Stephens et al., 1997; Ruan et al., 2002).

Activity of PPAR- $\gamma$ also could play a fundamental regulatory role in the attenuation or counterregulation of the response to exogenous TNF- $\alpha$. Indeed, nonruminant data indicated that activation of PPAR- $\gamma$ can attenuate the negative metabolic effects of TNF- $\alpha$ on adipocytes, thus preventing a decrease in insulin-mediated glucose uptake and downregulation of adipocyte gene expression (Szalkowski et al., 1995). The present data clearly demonstrated that PPARG abundance was not impaired in OVE cows and was greater compared with CON cows when challenged with TNF- $\alpha$. As such, two potential mechanisms could explain the lack of TNF- $\alpha$ effect. (1) Greater basal abundance of $P P A R G$ in response to positive energy balance ( $\mathrm{Ji}$ et al., 2014; Bahnamiri et al., 2018) coupled with the possibility that the short-term effect of TNF- $\alpha$ led to moderate release of fatty acids and their metabolites, which in turn contributed to activate PPARG (Cipolletta, 2014) and re-esterification within adipocytes. It is noteworthy to emphasize that TNF- $\alpha$ dose and time in the present study was responsible for a low-grade chronic inflammation response in rodent 3T3-L1 cells, and treatment with $10 \mathrm{ng} / \mathrm{mL}$ TNF- $\alpha$ only after $6 \mathrm{~h}$ led to downregulation of PPAR- $\gamma$ (Kim et al., 2006). (2) Because of macrophage infiltration, at least in nonruminants, in vitro studies with minced AT compared with cell lines generate different outcomes (Ferrante, 2013) in part due to specialized functional properties in a process known as polarization (Martinez et al., 2006). In rodents and humans, M1 polarization induces macrophages to express a proinflammatory response. In contrast, M2 macrophages are considered alternatively activated and promote tissue remodeling and resolution of inflammation (Sica and Mantovani, 2012). In nonruminants, evidence exists that PPAR- $\gamma$ has a significant effect on regulatory $\mathrm{T}$ lymphocytes toward different amounts of an anti-inflammatory functional phenotype. According to previous studies (Wohlfert et al., 2007; Cipolletta et al., 2012), PPAR- $\gamma$ drives regulatory lymphocyte function in the adipose blocking inflammation associated with obe- 
sity, supporting lipogenesis or adipogenesis pathways in adipocytes.

The lack of proinflammatory response in OVE compared with CON cows also could have resulted from a lower concentration of fatty acids (Table 2). In fact, SAT from CON cows overall had greater abundance of IL6 and NFKB1. Taken together, we speculated that greater abundance of adipogenic or lipogenic genes in the present study was due to a metabolic and physiological response of cells to the sustained increase in energy intake and not to TNF- $\alpha$ stimulation. The lower abundance of inflammation-related genes in SAT from OVE compared with CON cows, upregulation of $S A A 3$ in TNF- $\alpha$-challenged OVE cows, and upregulation of IL10 in TNF- $\alpha$-challenged CON cows underscored an unexpected degree of interaction between diet, insulin, and TNF- $\alpha$ challenge. Although few data are available on the abundance of SAA3 (or other SAA isotypes) in bovine adipose, one study reported an induction of $S A A 3$ transcription in mammary cells in response to challenge with bacterial components (Molenaar et al., 2009).

The TATA box binding protein-associated factor 9 (TAF9) is responsive to intracellular acetate concentrations within the intramuscular fat, particularly when animals are fed higher-fermentable diets (Moisá et al., 2013). The TATA box binding protein-associated factor proteins are associated with $\mathrm{TNF}-\alpha-$ induced protein 3 , which is activated by nuclear factor- $\kappa \mathrm{B}$ in response to proinflammatory signals such as TNF- $\alpha$ and can inhibit inflammation and programmed cell death (Ainbinder et al., 2002). As such, this mechanism can reduce damage that inflammation may elicit on tissues. Although not measured in the present study, we speculated that TAF9 has a role in the regulation of bovine AT response to cytokines, a process that was reported to be highly activated in dry or nonpregnant dairy cows overfed a similar high-energy diet as in the present study (Moisá et al., 2017).

Regardless of in vitro challenge, the upregulation of IL10, IL6, and NFKB1 in SAT from CON cows could have resulted from the fact we restricted them to only consume feed at the estimated energy requirements, hence resulting in local release of fatty acids from triacylglycerol. Fatty acids are potent regulators of the innate immune response through Toll-like receptors located on both immune and nonimmune cells that can recognize pathogen-associated molecular patterns on bacterial pathogens (Martins de Lima et al., 2007; Yaqoob and Calder, 2007). It should be noted, however, that it is unclear whether the fatty acids preparations used to address linkages with Toll-like receptor signaling are endotoxin-free. What is evident is that activation of Toll-like receptor-4 triggers an intracellular signaling cascade that can result in nuclear factor- $\mathrm{kB}$ translocation into the nucleus and upregulation of proinflammatory genes (Bannerman and Goldblum, 2003).

The fact that SAT from CON compared with OVE cows had greater abundance of IL10 suggests that SAT also produces anti-inflammatory factors, which may limit the overall proinflammatory response. Furthermore, the upregulation of IL10 in response to challenge with TNF- $\alpha$ may represent a counter regulatory mechanism to limit the proinflammatory action of this cytokine, considering also the carryover effect of the established immune response in SAT from CON cows.

\section{CONCLUSIONS}

Access to a high-energy diet for 6 wh resulted in greater final $\mathrm{BW}$ and increased mesenteric and perirenal adipose tissue mass without significant differences in BCS or carcass weight. Relying on BCS alone may not be sensitive enough over the short-term of a dry period to detect changes in internal fat stores that could affect metabolism and health. Contrary to our hypothesis that greater adipose mass deposition as a consequence of overconsumption of a high-energy diet could lead to insulin resistance, overfeeding energy facilitated rather than compromised the pathway of insulin signaling in SAT. The clearest evidence for the greater insulin sensitivity in OVE cows was the upregulation of the entire repertoire of adipogenic regulators and lipogenic genes measured. In fact, the present experiment does not support the hypothesis that overfeeding energy would stimulate an inflammatory response in bovine SAT (at least in nonlactating, nonpregnant dairy cows) as observed in obese nonruminants, and does not impair insulin signaling response in bovine SAT.

\section{ACKNOWLEDGMENTS}

V. Lopreiato received fellowship support from Interdepartmental Services Centre of Veterinary for Human and Animal Health, Department of Health Science, Magna Græcia University, Catanzaro (Italy) to train at the University of Illinois (Urbana). Afshin Hosseini (HO 4596/1-1) received fellowship support from the German Research Foundation (DFG, Germany). Abdulrahman Alharthi is a recipient of fellowship from King Saud University (Riyadh, Saudi Arabia) to perform his PhD studies at the University of Illinois (Urbana). Partial support for the conduct of the project was provided by the University of Illinois Campus Research Board, and Hatch funds under project ILLU-538-914, National Institute of Food and Agriculture, Washington, DC. The helpful discussions with J. K. Drackley (Department of 
Animal Sciences, University of Illinois, Urbana) during the design of the study are greatly appreciated.

\section{REFERENCES}

Ainbinder, E., M. Revach, O. Wolstein, S. Moshonov, N. Diamant, and R. Dikstein. 2002. Mechanism of rapid transcriptional induction of tumor necrosis factor alpha-responsive genes by NF-kappaB. Mol. Cell. Biol. 22:6354-6362.

AOAC International. 1995. Official Methods of Analysis of AOAC International. 16th ed. AOAC International, Arlington, VA.

Bahnamiri, H. Z., A. Zali, M. Ganjkhanlou, M. Sadeghi, and H. M. Shahrbabak. 2018. Regulation of lipid metabolism in adipose depots of fat-tailed and thin-tailed lambs during negative and positive energy balances. Gene 641:203-211.

Baldwin, R. L. t., K. R. McLeod, J. P. McNamara, T. H. Elsasser, and R. G. Baumann. 2007. Influence of abomasal carbohydrates on subcutaneous, omental, and mesenteric adipose lipogenic and lipolytic rates in growing beef steers. J. Anim. Sci. 85:2271-2282.

Bannerman, D. D., and S. E. Goldblum. 2003. Mechanisms of bacterial lipopolysaccharide-induced endothelial apoptosis. Am. J. Physiol. Lung Cell. Mol. Physiol. 284:L899-L914.

Bauman, D. E., R. E. Brown, and C. L. Davis. 1970. Pathways of fatty acid synthesis and reducing equivalent generation in mammary gland of rat, sow, and cow. Arch. Biochem. Biophys. 140:237-244.

Bionaz, M., B. J. Thering, and J. J. Loor. 2012. Fine metabolic regulation in ruminants via nutrient-gene interactions: saturated long-chain fatty acids increase expression of genes involved in lipid metabolism and immune response partly through PPAR-a activation. Br. J. Nutr. 107:179-191. https://doi.org/10.1017/ S0007114511002777.

Bradford, B. J., L. K. Mamedova, J. E. Minton, J. S. Drouillard, and B. J. Johnson. 2009. Daily injection of tumor necrosis factor-alpha increases hepatic triglycerides and alters transcript abundance of metabolic genes in lactating dairy cattle. J. Nutr. 139:1451-1456.

Brockman, R. P. 1978. Roles of glucagon and insulin in regulation of metabolism in ruminants-Review. Can. Vet. J. 19:55-62

Burrin, D. G., C. L. Ferrell, R. A. Britton, and M. Bauer. 1990. Level of nutrition and visceral organ size and metabolic activity in sheep. Br. J. Nutr. 64:439-448.

Cipolletta, D. 2014. Adipose tissue-resident regulatory T cells: Phenotypic specialization, functions and therapeutic potential. Immunology 142:517-525.

Cipolletta, D., M. Feuerer, A. Li, N. Kamei, J. Lee, S. E. Shoelson, C. Benoist, and D. Mathis. 2012. PPAR-gamma is a major driver of the accumulation and phenotype of adipose tissue Treg cells Nature 486:549-553.

Daniel, J. A., T. H. Elsasser, C. D. Morrison, D. H. Keisler, B. K. Whitlock, B. Steele, D. Pugh, and J. L. Sartin. 2003. Leptin, tumor necrosis factor-alpha (TNF), and CD14 in ovine adipose tissue and changes in circulating TNF in lean and fat sheep. J. Anim. Sci. 81:2590-2599.

DeFronzo, R. A., and D. Tripathy. 2009. Skeletal muscle insulin resistance is the primary defect in type 2 diabetes. Diabetes Care 32(Suppl. 2):S157-S163.

Drackley, J. K., R. L. Wallace, D. Graugnard, J. Vasquez, B. F. Richards, and J. J. Loor. 2014. Visceral adipose tissue mass in nonlactating dairy cows fed diets differing in energy density. J. Dairy Sci. 97:3420-3430

Edmonson, A. J., I. J. Lean, L. D. Weaver, T. Farver, and G. Webster. 1989. A body condition scoring chart for Holstein dairy cows. J. Dairy Sci. 72:68-78.

Ferrante, A. W., Jr. 2013. The immune cells in adipose tissue. Diabetes Obes. Metab. 15(Suppl 3):34-38.

Giorgino, F., L. Laviola, and J. W. Eriksson. 2005. Regional differences of insulin action in adipose tissue: insights from in vivo and in vitro studies. Acta Physiol. Scand. 183:13-30.

Hofmann, C., K. Lorenz, S. S. Braithwaite, J. R. Colca, B. J. Palazuk, G. S. Hotamisligil, and B. M. Spiegelman. 1994. Altered gene expression for tumor necrosis factor-alpha and its receptors during drug and dietary modulation of insulin resistance. Endocrinology 134:264-270.

Hotamisligil, G. S., A. Budavari, D. Murray, and B. M. Spiegelman. 1994. Reduced tyrosine kinase-activity of the insulin-receptor in obesity-diabetes - Central role of tumor-necrosis-factor-alpha. J. Clin. Invest. 94:1543-1549.

Hotamisligil, G. S., P. Peraldi, A. Budavari, R. Ellis, M. F. White, and B. M. Spiegelman. 1996. IRS-1-mediated inhibition of insulin receptor tyrosine kinase activity in TNF-alpha- and obesity-induced insulin resistance. Science 271:665-668.

Hotamisligil, G. S., N. S. Shargill, and B. M. Spiegelman. 1993. Adipose expression of tumor necrosis factor-alpha: Direct role in obesity-linked insulin resistance. Science 259:87-91.

Ibrahim, M. M. 2010. Subcutaneous and visceral adipose tissue: Structural and functional differences. Obes. Rev. 11:11-18.

Ji, P., J. K. Drackley, M. J. Khan, and J. J. Loor. 2014. Overfeeding energy upregulates peroxisome proliferator-activated receptor (PPAR)gamma-controlled adipogenic and lipolytic gene networks but does not affect proinflammatory markers in visceral and subcutaneous adipose depots of Holstein cows. J. Dairy Sci. 97:34313440

Ji, P., J. S. Osorio, J. K. Drackley, and J. J. Loor. 2012. Overfeeding a moderate energy diet prepartum does not impair bovine subcutaneous adipose tissue insulin signal transduction and induces marked changes in peripartal gene network expression. J. Dairy Sci. 95:4333-4351.

Kahn, B. B., and J. S. Flier. 2000. Obesity and insulin resistance. J. Clin. Invest. 106:473-481.

Kahn, C. R. 1978. Insulin resistance, insulin insensitivity, and insulin unresponsiveness: a necessary distinction. Metabolism 27(Suppl 2):1893-1902

Khan, M. J., C. B. Jacometo, D. E. Graugnard, M. N. Correa, E. Schmitt, F. Cardoso, and J. J. Loor. 2014. Overfeeding dairy cattle during late-pregnancy alters hepatic PPARalpha-regulated pathways including hepatokines: impact on metabolism and peripheral insulin sensitivity. Gene Regul. Syst. Bio. 8:97-111.

Kim, J. B., and B. M. Spiegelman. 1996. ADD1/SREBP1 promotes adipocyte differentiation and gene expression linked to fatty acid metabolism. Genes Dev. 10:1096-1107.

Kim, J. Y., K. Tillison, J. H. Lee, D. A. Rearick, and C. M. Smas, 2006. The adipose tissue triglyceride lipase ATGL/PNPLA2 is downregulated by insulin and TNF-alpha in 3T3-L1 adipocytes and is a target for transactivation by PPARgamma. Am. J. Physiol. Endocrinol. Metab. 291:E115-E127.

Lafontan, M. and M. Berlan. 2003. Do regional differences in adipocyte biology provide new pathophysiological insights? Trends Pharmacol. Sci. 24:276-283.

Le Lay, S., I. Lefrere, C. Trautwein, I. Dugail, and S. Krief. 2002. Insulin and sterol-regulatory element-binding protein-1c (SREBP-1C) regulation of gene expression in $3 \mathrm{~T} 3-\mathrm{L} 1$ adipocytes. Identification of CCAAT/enhancer-binding protein beta as an SREBP-1C target. J. Biol. Chem. 277:35625-35634.

Loor, J. J., M. Bionaz, and J. K. Drackley. 2013. Systems physiology in dairy cattle: nutritional genomics and beyond. Annu. Rev. Anim. Biosci. 1:365-392. https://doi.org/10.1146/annurev-animal $-031412-103728$

Martinez, F. O., S. Gordon, M. Locati, and A. Mantovani. 2006. Transcriptional profiling of the human monocyte-to-macrophage differentiation and polarization: new molecules and patterns of gene expression. J. Immunol. 177:7303-7311.

Martins de Lima, T., R. Gorjao, E. Hatanaka, M. F. Cury-Boaventura, E. P. Portioli Silva, J. Procopio, and R. Curi. 2007. Mechanisms by which fatty acids regulate leucocyte function. Clin. Sci. 113:65-77.

McCann, J. P., and T. J. Reimers. 1985. Glucose response to exogenous insulin and kinetics of insulin metabolism in obese and lean heifers. J. Anim. Sci. 61:612-618.

McNamara, J. P., J. H. Harrison, R. L. Kincaid, and S. S. Waltner 1995. Lipid metabolism in adipose tissue of cows fed high fat diets during lactation. J. Dairy Sci. 78:2782-2796.

Moisá, S. J., P. Ji, J. K. Drackley, S. L. Rodriguez-Zas, and J. J. Loor. 2017. Transcriptional changes in mesenteric and subcutaneous 
adipose tissue from Holstein cows in response to plane of dietary energy. J. Anim. Sci. Biotechnol. 8:85.

Moisá, S. J., D. W. Shike, W. T. Meteer, D. Keisler, D. B. Faulkner, and J. J. Loor. 2013. Yin yang 1 and adipogenic gene network expression in longissimus muscle of beef cattle in response to nutritional management. Gene Regul. Syst. Bio. 7:71-83.

Molenaar, A. J., D. P. Harris, G. H. Rajan, M. L. Pearson, M. R. Callaghan, L. Sommer, V. C. Farr, K. E. Oden, M. C. Miles, R. S. Petrova, L. L. Good, K. Singh, R. D. McLaren, C. G. Prosser, K. S. Kim, R. J. Wieliczko, M. H. Dines, K. M. Johannessen, M. R. Grigor, S. R. Davis, and K. Stelwagen. 2009. The acute-phase protein serum amyloid A3 is expressed in the bovine mammary gland and plays a role in host defence. Biomarkers 14:26-37.

Mukesh, M., M. Bionaz, D. E. Graugnard, J. K. Drackley, and J. J. Loor. 2010. Adipose tissue depots of Holstein cows are immune responsive: inflammatory gene expression in vitro. Domest. Anim. Endocrinol. 38:168-178.

Nestel, P. J., A. Poyser, R. L. Hood, S. C. Mills, M. R. Willis, L. J. Cook, and T. W. Scott. 1978. The effect of dietary fat supplements on cholesterol metabolism in ruminants. J. Lipid Res. 19:899-909.

NRC. 2001. Nutrient Requirements of Dairy Cattle. 7th rev. ed. ed. Natl. Acad. Press, Washington, DC.

Ofei, F., S. Hurel, J. Newkirk, M. Sopwith, and R. Taylor. 1996. Effects of an engineered human anti-TNF-alpha antibody (CDP571) on insulin sensitivity and glycemic control in patients with NIDDM. Diabetes 45:881-885.

Osorio, J. S., E. Trevisi, P. Ji, J. K. Drackley, D. Luchini, G. Bertoni, and J. J. Loor. 2014. Biomarkers of inflammation, metabolism, and oxidative stress in blood, liver, and milk reveal a better immunometabolic status in peripartal cows supplemented with Smartamine M or MetaSmart. J. Dairy Sci. 97:7437-7450. https://doi .org/10.3168/jds.2013-7679.

Petterson, J. A., F. R. Dunshea, R. A. Ehrhardt, and A. W. Bell. 1993. Pregnancy and undernutrition alter glucose metabolic responses to insulin in sheep. J. Nutr. 123:1286-1295.

Reynolds, C. K., P. C. Aikman, B. Lupoli, D. J. Humphries, and D. E. Beever. 2003. Splanchnic metabolism of dairy cows during the transition from late gestation through early lactation. J. Dairy Sci. 86:1201-1217.

Reynolds, C. K., B. Durst, B. Lupoli, D. J. Humphries, and D. E. Beever. 2004. Visceral tissue mass and rumen volume in dairy cows during the transition from late gestation to early lactation. J. Dairy Sci. 87:961-971.

Reynolds, C. K., and G. B. Huntington. 1988. Partition of portaldrained visceral net flux in beef steers. 2 . Net flux of volatile fatty acids, D-beta-hydroxybutyrate and L-lactate across stomach and post-stomach tissues. Br. J. Nutr. 60:553-562.

Reynolds, C. K., G. B. Huntington, H. F. Tyrrell, and P. J. Reynolds. 1988. Net metabolism of volatile fatty acids, D-beta-hydroxybutyrate, nonesterifield fatty acids, and blood gasses by portal-drained viscera and liver of lactating Holstein cows. J. Dairy Sci. 71:23952405.

Ronti, T., G. Lupattelli, and E. Mannarino. 2006. The endocrine function of adipose tissue: An update. Clin. Endocrinol. (Oxf.) 64:355-365.

Rosen, E. D., and B. M. Spiegelman. 2001. PPARgamma: A nuclear regulator of metabolism, differentiation, and cell growth. J. Biol. Chem. 276:37731-37734.

Rosen, E. D., and B. M. Spiegelman. 2006. Adipocytes as regulators of energy balance and glucose homeostasis. Nature 444:847-853.
Ruan, H., P. D. Miles, C. M. Ladd, K. Ross, T. R. Golub, J. M. Olefsky, and H. F. Lodish. 2002. Profiling gene transcription in vivo reveals adipose tissue as an immediate target of tumor necrosis factor-alpha: Implications for insulin resistance. Diabetes 51:3176-3188.

Saltiel, A. R., and C. R. Kahn. 2001. Insulin signalling and the regulation of glucose and lipid metabolism. Nature 414:799-806.

Schoenberg, K. M., and T. R. Overton. 2011. Effects of plane of nutrition and 2,4-thiazolidinedione on insulin responses and adipose tissue gene expression in dairy cattle during late gestation. J. Dairy Sci. 94:6021-6035.

Sica, A., and A. Mantovani. 2012. Macrophage plasticity and polarization: In vivo veritas. J. Clin. Invest. 122:787-795.

Staubs, P. A., J. G. Nelson, D. R. Reichart, and J. M. Olefsky. 1998. Platelet-derived growth factor inhibits insulin stimulation of insulin receptor substrate-1-associated phosphatidylinositol 3-kinase in 3T3-L1 adipocytes without affecting glucose transport. J. Biol. Chem. 273:25139-25147.

Stephens, J. M., J. Lee, and P. F. Pilch. 1997. Tumor necrosis factoralpha-induced insulin resistance in 3T3-L1 adipocytes is accompanied by a loss of insulin receptor substrate-1 and GLUT4 expression without a loss of insulin receptor-mediated signal transduction. J. Biol. Chem. 272:971-976.

Stephens, J. M., and P. H. Pekala. 1991. Transcriptional repression of the Glut4 and C/Ebp genes in 3t3-L1 adipocytes by tumornecrosis-factor-alpha. J. Biol. Chem. 266:21839-21845.

Stephens, J. M., and P. H. Pekala. 1992. Transcriptional repression of the C/Ebp-Alpha and Glut4 genes in 3t3-L1 adipocytes by tumornecrosis-factor-alpha-Regulation Is coordinate and independent of protein-synthesis. J. Biol. Chem. 267:13580-13584.

Szalkowski, D., S. White-Carrington, J. Berger, and B. Zhang. 1995. Antidiabetic thiazolidinediones block the inhibitory effect of tumor necrosis factor-alpha on differentiation, insulin-stimulated glucose uptake, and gene expression in 3T3-L1 cells. Endocrinology 136:1474-1481.

Van Harmelen, V., F. Lonnqvist, A. Thorne, A. Wennlund, V. Large, S. Reynisdottir, and P. Arner. 1997. Noradrenaline-induced lipolysis in isolated mesenteric, omental and subcutaneous adipocytes from obese subjects. Int. J. Obes. Relat. Metab. Disord. 21:972979

Vidal-Puig, A. J., R. V. Considine, M. Jimenez-Linan, A. Werman, W. J. Pories, J. F. Caro, and J. S. Flier. 1997. Peroxisome proliferatoractivated receptor gene expression in human tissues. Effects of obesity, weight loss, and regulation by insulin and glucocorticoids. J. Clin. Invest. 99:2416-2422.

Wohlfert, E. A., F. C. Nichols, E. Nevius, and R. B. Clark. 2007. Peroxisome proliferator-activated receptor gamma (PPARgamma) and immunoregulation: enhancement of regulatory T cells through PPARgamma-dependent and -independent mechanisms. J. Immunol. 178:4129-4135.

Wright, I., and A. Russel. 1984. Partition of fat, body composition and body condition score in mature cows. Anim. Sci. 38:23-32.

Yang, M., J. H. Fu, X. Y. Lan, Y. J. Sun, C. Z. Lei, C. L. Zhang, and H. Chen. 2013. Effect of genetic variations within the SH2B2 gene on the growth of Chinese cattle. Gene 528:314-319.

Yaqoob, P., and P. C. Calder. 2007. Fatty acids and immune function: New insights into mechanisms. Br. J. Nutr. 98:S41-S45. 